\title{
Communities of metazoan parasites of two fishes of the Proterorhinus genus (Actinopterygii: Gobiidae)
}

\author{
YURIY KVACH ${ }^{1}$, MEHMET CEMAL OĞUZ \\ ${ }^{1}$ Odessa Branch of the Institute of Biology of the Southern Seas, NAS of Ukraine, Vul. Pushkinska 37, 65125 Odessa, \\ Ukraine, E-mail: quach@paco.net; ${ }^{2}$ Department of Biology, Faculty of Art and Science, Ataturk University, \\ 25240 Erzurum, Turkey
}

\begin{abstract}
Summary
Metazoan parasite communities of two gobiids, Proterorhinus marmoratus and $P$. semilunaris, which are common small-sized fishes native for the Black Sea basin, were studied. The parasite component community of $P$. marmoratus is represented by 11 species (one monogenean, one cestode, five digeneans, two nematodes, and two acanthocephalans). $P$. semilunaris had 5 species (one monogenean, one cestode, one digenean, one nematode, and one acanthocephalan). Acanthocephaloides propinquus has a great tendency to join the infracommunity. The differences between the parasite component communities of two Proterorhinus gobies are explained by different quality of habitats and available intermediate hosts. The component community of parasites of $P$. marmoratus is formed by brackish-water and marine parasite species, and that of $P$. semilunaris consists of limnetic parasite species. The euryhaline G. proterorhini is the only parasite species found in both $P$. marmoratus and $P$. semilunaris. In both species of gobiids, the main abundant parasite species $(A$. propinquus in $P$. marmoratus and Nicolla skrjabini in $P$. semilunaris) infest the host by feeding on crustaceans.
\end{abstract}

Keywords: Proterorhinus, Gobiidae, Parasite community, Black Sea, Dniester River

\section{Introduction}

The gobiids of Proterorhinus genus are common smallsized fishes of the Ponto-Caspian basin. This genus is represented by five species: Proterorhinus marmoratus (Pallas, 1814), P. nasalis (Filippi, 1863), P. semipellucidus Kessler, 1863, P. semilunaris Heckel, 1837, P. tataricus Freyhof and Naseka, 2007 (Stepien \& Tumeo, 2006; Freyhof \& Naseka, 2007; Neilson \& Stepien, 2009). Two of these species inhabit the brackish waters of the Black Sea (P. marmoratus) and the southern Caspian Sea (P. nasalis). The western freshwater tubenose goby $P$. semilunaris is native to the fresh waters of the Black Sea basin and the Maritza and Struma rivers draining the Aegean Sea (Stepien \& Tumeo, 2006; Kottelat \& Freyhof, 2007), but are mentioned as non-indigenous in the upper streams of the Danube river (Harka, 1990; Erös et al., 2005; Prášek \& Jurajda, 2005), the Dnieper river (Pinchuk et al., 1985; Rizevsky et al., 2007), the Rhine-Main River system (North Sea basin) (Reinartz \& Hilbrich, 2000; Freyhof, 2003; Copp et al., 2005, Manné \& Poulet, 2008), the Vistula River (Grabowska et al., 2008), and the Laurentian Great Lakes (Jude et al., 1992).

Extensive data has been published on the parasites of $P$. marmoratus in the Sevastopol Bay (Naidenova, 1974; Gaevskaya \& Dmitrieva, 1997), the North-Western Black Sea (Chernyshenko, 1960, 1966; Machkevsky et al., 1990; Kvach, 2005), and the Bulgarian coastal Lake Beloslavsko (Margaritov, 1960). However, the parasites of P. semilunaris in native habitats are studied only in the lower and middle Danube River (Chiriac \& Udrescu, 1957; Vojtek, 1964; Ergens, 1962, 1967) and in the small rivers of the northern coast of the Sea of Azov (Chaplina \& Antsyshkina, 1961). P. semilunaris was long considered a junior synonym of P. marmoratus (Berg, 1949; Smirnov, 1986), but was resurrected by Stepien and Tumeo (2006). Therefore, no comparative studies were made.

So, in view of the invasive status of $P$. semilunaris and its similarity with $P$. marmoratus, the objective of this study was to compare the communities of metazoan parasites of these two gobiids in their native habitats of the NorthWestern Black Sea region (then NWBS).

\section{Material and Methods}

The fish were caught by deep-net $(100 \mathrm{~cm} \times 50 \mathrm{~cm} ; 5 \mathrm{~mm}$ mesh size) in the summer period of $2004-2006$ at 7 localities in 5 water bodies: Tyligul Estuary, Hryhorivsky Estuary, Gulf of Odessa, Sukhyi Estuary, and Dniester 


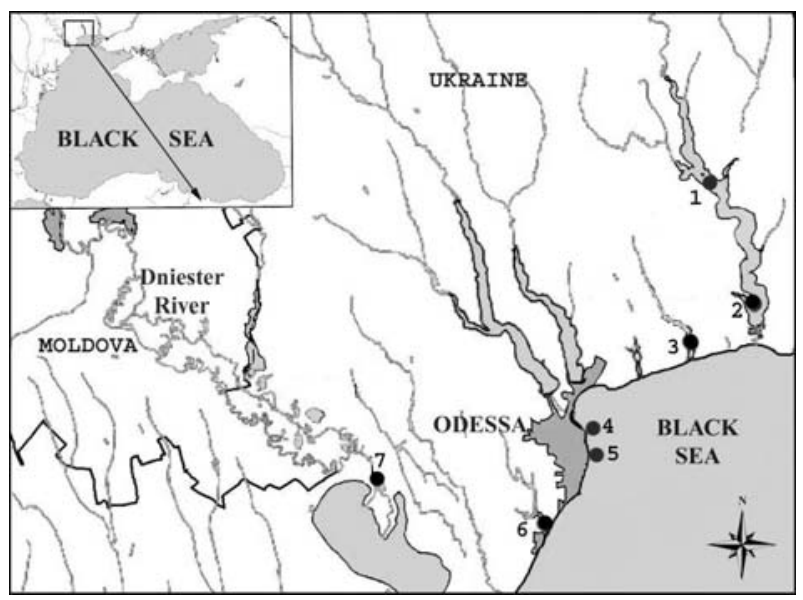

Fig. 1. Schematic map of the investigation area. Black circles: sampling localities

River Delta (Fig. 1; Table 1). During the analysis the localities \#\#1, 2 (Tyligul Estuary) and \#\#4, 5 (Gulf of Odessa) were grouped according to the water body they were taken from (Table 1). In total, 113 gobies (98 ind. of $P$. marmaratus and 15 ind. of $P$. semilunaris) were examined for parasites (Table 1). The standard length (SL, cm) of individual fish was measured first.

Parasitological terminology follows Bush et al. (1997) and Zander (1998). The prevalence (P, \%), intensity (presented as intensity range, IR), mean intensity (MI), and abundance (A) were calculated according to Bush et al. (1997). The importance of parasites is judged by an altered core/satellite concept according to their abundance: $>2=$ core species, $0.6-2=$ secondary species; $0.2-0.6=$ satellite species; and $<0.2=$ rare species (Zander et al., 2000). The tendency to join the infracommunity was evaluated according to the Infracommunity Index, ICI (Zander, 2004):

$\mathrm{ICI}=\frac{M i j}{N j \times I j}$,

where $M i j$ was the ratio (number) of multiple infected hosts $j$ with parasite $i$ and other parasites, $N j$ was the ratio (numbers) of infected hosts $j$, and $I j$ was the mean of parasite species in host $j$ (= mean infracommunity). The great tendency to join the community was determined by the ICI level more then 0.30 (Zander, 2004).

To compare the parasite faunas the Index of CzekanowskiSørensen, ICS (Czekanowski, 1909; Sørensen, 1948), was used:

$\mathrm{ICS}=\frac{2 c}{a+b} \times 100 \%$,

where $a$ was the number of parasite species found in host $\mathrm{A}, b$ was the number of parasite species found in host B, and $c$ was the number of parasite species infecting both hosts.

Abbreviations of names of parasite larval stages were used as follows: pl - pleurocercoid, met - metacercaria, L3 third stage larval, ca - cystacanth.

\section{Results}

P. marmoratus was found in brackish-water localities: Tyligul, Hryhorivsky, Sukhyi estuaries, and the Gulf of Odessa, but $P$. semilunaris occurred only in the Dniester River delta (Table 1). The metazoan parasite component community of $P$. marmoratus is represented by 11 species, including one monogenean, one cestode, five digeneans, two nematodes, and two acanthocephalans (Table 2). Only one species, the monogenean Gyrodactylus proterorhini Ergens, 1967, occurred in both gobiids. Aside from this monogenean, the parasite component community of $P$. semilunaris was comprised of another four species (Table 2 ). The similarity between the metazoan parasite fauna of $P$. marmoratus and P. semilunaris (ICS) was $12.5 \%$.

The analysis of importance of parasites follows the scale of Zander et al. (2000) which shows that there are five core species in the parasite component community of $P$. marmoratus: Cryptocotyle concavum (Creplin, 1825) was a core species in all localities of occurrence (except the Gulf of Odessa), C. lingua (Creplin, 1825) in all localities, $\mathrm{Ti}^{-}$ moniella imbutiforme (Molin, 1859) was a core species only in the Hryhorivsky Estuary, and Acanthocephaloides propinquus (Dujardin, 1845) in all localities (except the Hryhorivsky Estuary) (Table 2). The only secondary spe-

Table 1. The sampling localities and number of sampled gobiids of two Proterorhinus species

\begin{tabular}{|c|c|c|c|c|c|}
\hline Host species & \multicolumn{4}{|c|}{ Proterorhinus marmoratus } & P. semilunaris \\
\hline Name of water bodies & $\begin{array}{l}\text { Tyligul } \\
\text { Estuary }\end{array}$ & $\begin{array}{l}\text { Hryhorivsky } \\
\text { Estuary }\end{array}$ & $\begin{array}{l}\text { Gulf of } \\
\text { Odessa }\end{array}$ & $\begin{array}{l}\text { Sukhyi } \\
\text { Estuary }\end{array}$ & $\begin{array}{l}\text { Dniester } \\
\text { River }\end{array}$ \\
\hline $\begin{array}{l}\text { Number of localities according to } \\
\text { Fig. } 1\end{array}$ & 1,2 & 3 & 4,5 & 6 & 7 \\
\hline Coordinates & $\begin{array}{l}46^{\circ} 53^{\prime} \mathrm{N} \\
31^{\circ} 03^{\prime} \mathrm{E} \\
46^{\circ} 41^{\prime} \mathrm{N} \\
31^{\circ} 09^{\prime} \mathrm{E}\end{array}$ & $\begin{array}{l}46^{\circ} 37^{\prime} \mathrm{N} \\
31^{\circ} 00^{\prime} \mathrm{E}\end{array}$ & $\begin{array}{l}46^{\circ} 28^{\prime} \mathrm{N} \\
31^{\circ} 45^{\prime} \mathrm{E} \\
46^{\circ} 26^{\prime} \mathrm{N} \\
31^{\circ} 46^{\prime} \mathrm{E}\end{array}$ & $\begin{array}{l}46^{\circ} 19^{\prime} \mathrm{N} \\
31^{\circ} 40^{\prime} \mathrm{E}\end{array}$ & $\begin{array}{l}46^{\circ} 27^{\prime} \mathrm{N} \\
31^{\circ} 11^{\prime} \mathrm{E}\end{array}$ \\
\hline $\begin{array}{l}\text { Number of fish hosts } \\
\text { Standard length, cm (m } \pm \text { SD) } \\
\text { Number of infected hosts } \\
\text { Number of uninfected hosts }\end{array}$ & $\begin{array}{c}12 \\
5.0 \pm 3.1 \\
8(66.7 \%) \\
4(33.3 \%) \\
\end{array}$ & $\begin{array}{c}5 \\
5.8 \pm 0.8 \\
5 \\
0 \\
\end{array}$ & $\begin{array}{c}46 \\
4.6 \pm 0.6 \\
40(87.0 \%) \\
6(13.0 \%)\end{array}$ & $\begin{array}{c}35 \\
5.0 \pm 0.9 \\
30(85.7 \%) \\
5(14.3 \%) \\
\end{array}$ & $\begin{array}{c}15 \\
3.1 \pm 0.8 \\
11(73.3 \%) \\
4(26.7 \%) \\
\end{array}$ \\
\hline
\end{tabular}


cies was $A$. propinquus in the Hryhorivsky Estuary. The monogenean $G$. proterorhini (in the Sukhyi Estuary and the Gulf of Odessa), metacercariae of $C$. concavum (in the Gulf of Odessa), nematode Dichelyne minutus (Rudolphi, 1819) (in the Gulf of Odessa and the Hryhorivsky Estuary), and acanthocephalan Telosentis exiguus (von Linstow, 1901) (in the Sukhyi Estuary) were satellite species. In some water bodies $T$. imbutiforme (Tyligul Estuary), $D$. minutus (estuaries Tyligul and Sukhyi), and T. exiguus (Sukhyi Estuary) were rare. The cestode Proteocephalus gobiorum Dogiel et Bychowsky, 1939, digeneans Magnibursatus skrjabini (Vlasenko, 1931) and Pygidiopsis genata Looss, 1907, and the nematode Streptocara crassicauda (Creplin, 1829) (in the Gulf of Odessa) also were rare parasites of $P$. marmoratus at all localities of their occurrence. In $P$. semilunaris, only the digenean Nicolla skrjabini
(Iwanitzky 1928) was a core species in its component community, while other species were rare (Table 2).

In both host species the single ectoparasite (G. proterorhini) was found, being located on fins and skin (Table 3). The Cryptocotyle metacercariae encysted in skin and fins were rather abundant in $P$. marmoratus, but were absent in P. semilunaris (Table 3 ). Two species, A. propinquus and $T$. exiguus, were found in three microhabitats (stomach, intestine, and cloaca) with the highest number of $A$. propinquus in the cloaca, and T. exiguus in the intestine. The digenean N. skrjabini was also found in all three microhabitats being most abundant in the intestine of $P$. semilunaris (Table 3).

The parasite infracommunity of $P$. marmoratus is composed of one to six species. The fish infected with one parasite species made up $33.7 \%$; in most cases they were

Table 2. The component communities of two Proterorhinus species in the North-Western Black Sea and the Dniester River

\begin{tabular}{|c|c|c|c|c|c|c|}
\hline \multirow{3}{*}{$\begin{array}{l}\text { Host species } \\
\text { Localities }\end{array}$} & & \multicolumn{4}{|c|}{ Proterorhinus marmoratus } & \multirow{3}{*}{$\begin{array}{c}P . \text { semilunaris } \\
\text { Dniester } \\
\text { River }\end{array}$} \\
\hline & & Tyligul & Hryhorivsky & Gulf of & Sukhyi & \\
\hline & & Estuary & Estuary & Odessa & Estuary & \\
\hline \multicolumn{2}{|c|}{1} & 2 & 3 & 4 & 5 & 6 \\
\hline \multicolumn{7}{|l|}{ MONOGENEA } \\
\hline Gyrodactylus & $\mathrm{P}$ & & & 10.9 & 22.9 & 6.7 \\
\hline \multirow{3}{*}{ proterorhini } & IR & & & $1-3$ & $1-3$ & 1 \\
\hline & MI & & & $1.4 \pm 0.9$ & $1.5 \pm 0.8$ & 1.0 \\
\hline & A & & & 0.2 & 0.3 & 0.1 \\
\hline \multicolumn{7}{|l|}{ CESTODA } \\
\hline Triaenophorus & $\mathrm{P}$ & & & & & 6.7 \\
\hline \multirow[t]{3}{*}{ crassus pl } & IR & & & & & 1 \\
\hline & MI & & & & & 1.0 \\
\hline & A & & & & & 0.1 \\
\hline Proteocephalus & $\mathrm{P}$ & 8.3 & & & 2.9 & \\
\hline \multirow[t]{3}{*}{ gobiorum } & IR & 1 & & & 1 & \\
\hline & MI & 1.0 & & & 1 & \\
\hline & A & 0.1 & & & 0.03 & \\
\hline \multicolumn{7}{|l|}{ DIGENEA } \\
\hline Cryptocotyle & $\mathrm{P}$ & 41.7 & 3 from 5 & 15.2 & 28.6 & \\
\hline \multirow[t]{3}{*}{ concavum met } & IR & $1-20$ & $1-208$ & $1-9$ & $1-54$ & \\
\hline & MI & $7.8 \pm 9.0$ & $86.3 \pm 108.2$ & $3.3 \pm 3.2$ & $12.5 \pm 20.2$ & \\
\hline & A & 3.3 & 51.8 & 0.5 & 3.6 & \\
\hline \multirow[t]{4}{*}{ C. lingua met } & $\mathrm{P}$ & 16.7 & 2 from 5 & 34.8 & 11.4 & \\
\hline & IR & $15-20$ & $53-201$ & $1-24$ & $2-52$ & \\
\hline & MI & $17.5 \pm 3.5$ & $127.0 \pm 104.7$ & $6.4 \pm 6.0$ & $27.0 \pm 27.2$ & \\
\hline & A & 2.9 & 50.8 & 2.2 & 3.1 & \\
\hline Magnibursatus & $\mathrm{P}$ & & & 2.2 & 8.6 & \\
\hline \multirow[t]{3}{*}{ skrjabini } & IR & & & 1 & 1 & \\
\hline & MI & & & 1.0 & $1.0 \pm 0.0$ & \\
\hline & A & & & 0.02 & 0.1 & \\
\hline Nicolla & $\mathrm{P}$ & & & & & 73.3 \\
\hline \multirow[t]{3}{*}{ skrjabini } & IR & & & & & $1-9$ \\
\hline & MI & & & & & $3.7 \pm 2.5$ \\
\hline & A & & & & & 2.7 \\
\hline Pygidiopsis & $\mathrm{P}$ & & & 2.2 & & \\
\hline \multirow[t]{3}{*}{ genata met } & IR & & & 6 & & \\
\hline & MI & & & 6.0 & & \\
\hline & A & & & 0.1 & & \\
\hline Timoniella & $\mathrm{P}$ & 8.3 & 1 from 5 & & & \\
\hline \multirow[t]{3}{*}{ imbutiforme met } & IR & 1 & 51 & & & \\
\hline & MI & 1.0 & 51.0 & & & \\
\hline & $\mathrm{A}$ & 0.1 & 10.2 & & & \\
\hline
\end{tabular}




\begin{tabular}{|c|c|c|c|c|c|c|}
\hline 1 & & 2 & 3 & 4 & 5 & 6 \\
\hline \multicolumn{7}{|l|}{ NEMATODA } \\
\hline Dichelyne & $\mathrm{P}$ & 8.3 & 1 from 5 & 23.9 & 8.6 & \\
\hline \multirow[t]{3}{*}{ minutus } & IR & 1 & 1 & $1-5$ & $1-2$ & \\
\hline & MI & 1.0 & 1.0 & $1.6 \pm 1.2$ & $1.3 \pm 0.6$ & \\
\hline & A & 0.1 & 0.2 & 0.4 & 0.1 & \\
\hline Eustrongylides & $\mathrm{P}$ & & & & & 6.7 \\
\hline \multirow[t]{3}{*}{ excisus L3 } & IR & & & & & 1 \\
\hline & MI & & & & & 1.0 \\
\hline & A & & & & & 0.1 \\
\hline Streptocara & $\mathrm{P}$ & & & 8.7 & & \\
\hline \multirow[t]{3}{*}{ crassicauda L3 } & IR & & & $1-2$ & & \\
\hline & MI & & & $1.3 \pm 0.5$ & & \\
\hline & A & & & 0.1 & & \\
\hline \multicolumn{7}{|l|}{ ACANTHOCEPHALA } \\
\hline Acanthocephaloides & $\mathrm{P}$ & 58.3 & 4 from 5 & 45.7 & 77.1 & \\
\hline \multirow[t]{3}{*}{ propinquus } & IR & $1-13$ & $1-4$ & $1-32$ & $1-49$ & \\
\hline & MI & $3.6 \pm 4.4$ & $1.8 \pm 1.5$ & $8.8 \pm 8.4$ & $10.1 \pm 12.1$ & \\
\hline & A & 2.1 & 1.4 & 4.0 & 7.8 & \\
\hline \multirow[t]{4}{*}{ Acanthocephalus lucii } & $\mathrm{P}$ & & & & & 6.7 \\
\hline & IR & & & & & 1 \\
\hline & MI & & & & & 1.0 \\
\hline & A & & & & & 0.1 \\
\hline Telosentis & $\mathrm{P}$ & & & 4.3 & 17.1 & \\
\hline \multirow[t]{3}{*}{ exiguus } & IR & & & 1 & $1-3$ & \\
\hline & MI & & & $1.0 \pm 0.0$ & $1.7 \pm 1.0$ & \\
\hline & $\mathrm{A}$ & & & 0.04 & 0.3 & \\
\hline Species number & & 6 & 5 & 9 & 8 & 5 \\
\hline
\end{tabular}

Look "Material and Methods" for abbreviations.

infected with $A$. propinquus. The gobies infected with two parasites species made up $31.6 \%$, three parasites species $12.2 \%$, and four $-4.1 \%$. Five and six parasite species occurred in only one goby individual each $(1.0 \%$ of examined $P$. marmoratus). Most of the examined $P$. semilunaris ( 9 from 15 individuals or $60.0 \%$ ) were infected with only one parasite species, N. skrjabini. The infracommunity of one gobiid individual $(6.7 \%)$ was composed by two parasite species, G. proterorhini and N. skrjabini, located in different microhabitats. The infracommunity of another gobiid individual harbored four parasite species, Triaenophorus crassus Forel, 1868, N. skrjabini, Eustrongylides excisus Jägerskiöld, 1909, and Acanthocephalus lucii (Müller, 1776), two of which (T. crassus, E. excisus) were located in muscles, and the remaining two species $(N$. skrjabini, A. lucii) in the digestive tract.

According to the Infracommunity Index (ICI), A. propinquus in the Sukhyi Estuary has the great tendency to join the community (Table 4). In other localities A. propinquus also shows high levels of this index.

\section{Discussion}

The species richness in the metazoan parasite fauna of $P$. marmoratus is similar to the data of previous investigations in the NWBS (11 species) (Chernyshenko, 1960, 1966; Machkevsky et al., 1990; Kvach, 2005). We found 8 parasite species, which were reported earlier (in comparing to the literature data ICS $=72.7 \%$ ) and three species occurred first: G. proterorhini, M. skrjabini, and S. crassicauda. The species richness is similar to that in the Sevastopol Bay (11 species) (Naidenova, 1974; Gaevskaya \& Dmitrieva, 1997), but the species composition was much different in our data (ICS $=27.3 \%$ ): only three species, $G$. proterorhini, C. concavum, and M. skrjabini, were recorded in both NWBS and Sevastopol Bay. According to the data of Margaritov (1960), in Bulgarian brackish-water Lake Beloslavsko, P. marmoratus infected with only one metazoan parasite species, Piscicola geometra L., 1758, which not found by us.

The literature data about the parasites of $P$. semilunaris in its native habitats are scarce (Table 5). In small rivers of the northern coast of the Sea of Azov two species, the digenean Plagioporus skrjabini Koval, 1951 and glochidiae of unionids, were found (Chaplina \& Antsyshkina, 1961). Another two parasite species, the monogenean $G$. proterorhini (sometime quoted as G. medius Kathariner, 1893 or G. arcuatus Bychowsky, 1933) and metacercariae of $A$. cobitidis proterorhini, were reported in the $P$. semilunaris original range in the Danube River (lower and middle stream) (Chiriac \& Udrescu, 1957; Vojtek, 1964; Ergens, 1962, 1967). The similarity between the Dniester River and the Danube River (ICS) was $28.6 \%$ (see Table 5). In contrast, the parasite fauna of the invasive $P$. semilunaris in non-native habitats, such as the Morava River and Lake St. Clair (North America), have been investigated rather extensively (Muzzall et al., 1995; Pronin et al., 1997; Koubková \& Baruš, 2000; Kvach \& Stepien, 2008) (Table 5). The maximum species richness of the metazoan parasite fauna of the invasive $P$. semilunaris in the Morava River (Czech Republic) is 13 species (Koubková \& Baruš, 2000). The data about $P$. semilunaris parasites in the Dniester River do not consist of any of the same species as in the Great Lakes, but the similarity with the Morava River basin is very low (ICS $=11.1 \%$ ) (Koubková \& Baruš, 2000; Kvach \& Stepien, 2008). 


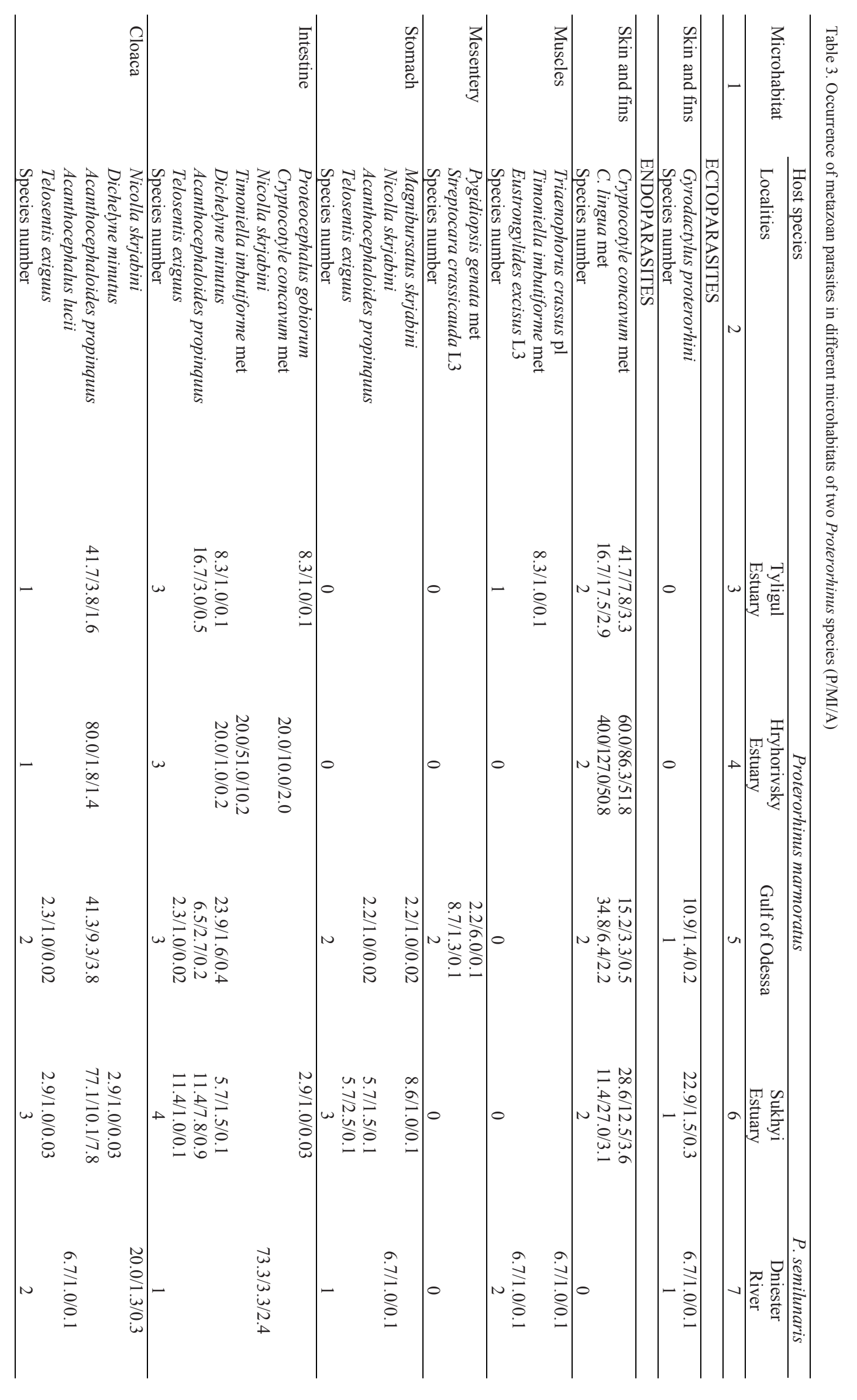


Table 4. Infracommunity index. Bold: the great tendency to join the infracommunity

\begin{tabular}{|c|c|c|c|c|c|}
\hline \multirow{2}{*}{$\frac{\text { Host species }}{\text { Locality }}$} & \multicolumn{4}{|c|}{ Proterorhinus marmoratus } & \multirow{2}{*}{$\frac{\text { P. semilunaris }}{\text { Dniester River }}$} \\
\hline & $\begin{array}{l}\text { Tyligul } \\
\text { Estuary }\end{array}$ & $\begin{array}{c}\text { Hryhorivsky } \\
\text { Estuary }\end{array}$ & Gulf of Odessa & Sukhyi Estuary & \\
\hline Gyrodactylus proterorhini & & & 0.03 & 0.11 & 0.07 \\
\hline Triaenophorus crassus $\mathrm{pl}$ & & & & & 0.07 \\
\hline Proteocephalus gobiorum & 0.06 & & & 0.02 & \\
\hline Cryptocotyle concavum met & 0.24 & 0.20 & 0.07 & 0.16 & \\
\hline C. lingua met & 0.12 & 0.13 & 0.17 & 0.06 & \\
\hline Magnibursatus skrjabini & & & 0.01 & 0.05 & \\
\hline Nicolla skrjabini & & & & & 0.13 \\
\hline Pygidiopsis genata met & & & 0.01 & & \\
\hline Timoniella imbutiforme met & 0.06 & 0.07 & & & \\
\hline Dichelyne minutus & 0.06 & 0.07 & 0.09 & 0.05 & \\
\hline Eustrongylides excisus L3 & & & & & 0.07 \\
\hline Streptocara crassicauda L3 & & & 0.03 & & \\
\hline Acanthocephaloides propinquus & 0.24 & 0.20 & 0.22 & 0.31 & \\
\hline Acanthocephalus lucii & & & & & 0.07 \\
\hline Telosentis exiguus & & & 0.02 & 0.10 & \\
\hline
\end{tabular}

Digeneans are the most numerous parasites in the gobiid guild community in the northwestern Black Sea (Kvach, 2005). However, in P. semilunaris they are represented by a single species, N. skrjabini, which is also the only core species in its parasite fauna. The remaining four species (G. proterorhini, T. crassus, E. excisus, A. lucii) parasitizing $P$. semilunaris occurred in a single specimen each.

The monogenean $G$. proterorhini is a specific parasite of goby guild in the Black Sea basin. In the NWBS it had never before been reported. It is now mentioned as a rare species both in the sea and the Dniester River (Table 2). Another specialist parasite of goby guild in the Ponto-Caspian region is $P$. gobiorum. In the estuaries of the Black Sea this species is the most abundant in the grass goby, Zosterisessor ophiocephalus (Pallas, 1814) (Kvach, 2005). It is now also registered in P. marmoratus. Both specialists (G. proterorhini and P. gobiorum) have a low tendency to join the infracommunity in Proterorhinus fishes (Table 4). The ICI was highest for generalists like A. propinquus and C. concavum (in $P$. semilunaris the generalist trematode $N$. skrjabini attained the highest value of this index), which infest great number of hosts in the Black Sea basin. The high value of ICI for the generalist parasites shows the possibility of these hosts to engage in parasitic systems in new habitats. So, these gobiids play the important role in the realization of the parasites life cycles.

The most abundant parasites of both Proterorhinus species are parasites of the digestive tract. In P. marmoratus it was the acanthocephalan $A$. propinquus (most abundant in the cloaca), but in P. semilunaris it was the digenean N. skrjabini (Table 3). The source of infestation by these parasites were benthic organisms, which play the role of dietary items for the gobiids. The hosts of A. propinquus cystacanths are caprellid amphipods and isopods Idothea balthica basteri (de Buron and Chauvet, 2003; Belofastova, 2007). The hosts of metacercariae of $N$. skrjabini are also gammarids (Stenko, 1976). Crustaceans are the main pray item of the tubenose goby (Smirnov, 1986). Thus, in both species of gobiids, the main abundant parasite species infest the host as the host feeds on crustaceans.

Besides the typical parasites of the digestive tract of fish, free metacercariae (without cysts) of C. concavum (10 sp.) and $T$. imbutiforme $(51 \mathrm{sp}$.) occurred in the intestine of a goby from the Hryhorivsky Estuary (Table 3). A specimen of the marbled goby, Pomatoschistus marmoratus (Risso, 1810), was found in the digestive tract of this individual fish. It should be a source of occasional infestation of the tubenose goby with digeneans.

The parthenogenesis stages (sporocysts and rediae) of $C$. concavum develop in mudsnails of the Hydrobia genus (Zander et al., 1993). The gastropod Hydrobia acuta is one of the most abundant species in the Gulf of Odessa (Butenko, 2000) and it is also present in all brackish waters of the NWBS (Losovskaya et al., 2006). The cercariae actively penetrate through the skin of fishes (Naidenova, 1974); therefore the lithophilous P. marmoratus is easily invaded by cercariae.

The differences between the parasite component communities of two Proterorhinus gobies are induced by the habiting in different environmental conditions. The salinity of the most of water bodies where $P$. marmoratus caught is ranged from $10 \%$ in spring to $17 \%$ in summer $(\mathrm{V} . \mathrm{V}$. Adobovsky, P. C.), however, in the Tyligul Estuary it was $16-19 \%$, and in some bays was up to $21 \%$. In the Dni- 
ester River where $P$. semilunaris were caught the water is fresh. The parasite community of $P$. marmoratus consists of mostly $(63.6 \%)$ brackish-water species ( $P$. gobiorum, C. concavum, M. skrjabini, P. genata, T. imbutiforme, D. minutus, T. exiguus). Two marine (C. lingua, A. propinquus) and two euryhaline (G. proterorhini, S. crassicauda) species make up just $18.2 \%$ of the parasite community. The $1^{\text {st }}$ intermediate hosts of $C$. concavum, T. imbutiforme, and $C$. lingua are brackish-water Hydrobia mollusks (Maillard, 1975; Zander et al., 1993), which are absent in fresh waters. The life cycles of acanthocephalans are connected to marine and brackish-water amphipods (Dezfuli, 1989; de Buron \& Chauvet, 2003; Belofastova, 2007), and the life cycle of $D$. minutus to brackish-water polychaetes (Køie, 2001). Also, among the other $1^{\text {st }}$ intermediate hosts of $S$. crassicauda are brackish-water gammarids (Moravec, 1994). Thus, the life cycles of metazoan parasites of $P$. marmoratus connect this fish to the brackish-water benthic community.

The euryhaline G. proterorhini previously was found in various gobiids in the polyhaline waters of the Black Sea, such as the Crimean near-shores (Naidenova, 1974), and in the fresh waters of the Danube River drainage (Chiriac \& Udrescu, 1957; Ergens, 1962, 1967; Koubková \& Baruš, 2000; Ondračková et al., 2005). All other parasites found in P. semilunaris are limnetic and are typical for many fish species in European fresh waters. In addition, species such as N. skrjabini, E. excisus, and A. lucii, were noted in gobiids in brackish waters of the NWBS (Kvach, 2005), but they are absent in P. marmoratus.

Table 5. Metazoan parasite of Proterorhinus semilunaris in native and non-indigenous waters according to different authors $\left({ }^{1}-\right.$ current data;

${ }^{2}$ - Chaplina and Antsyshkina, 1961; ${ }^{3}$ - Chiriac and Udrescu, 1957; Vojtek, 1964; Ergens, 1962; 1967; ${ }^{4}$ - Koubková and Baruš, 2000; 5 - Muzzall et al., 1995; Pronin et al., 1997; Kvach and Stepien, 2008)

\begin{tabular}{|c|c|c|c|c|c|}
\hline \multirow[b]{2}{*}{ Locality } & \multicolumn{3}{|c|}{ Native } & \multicolumn{2}{|c|}{ Non-indigenous } \\
\hline & $\begin{array}{l}\text { Dniester } \\
\text { River }^{1}\end{array}$ & $\begin{array}{l}\text { Small rivers of } \\
\text { northern Azov } \\
\text { coast }^{2}\end{array}$ & $\begin{array}{c}\text { Lower and } \\
\text { Middle } \\
\text { Danube River } \\
\text { basin }^{3}\end{array}$ & Morava River ${ }^{4}$ & $\begin{array}{l}\text { Lake } \\
\text { St. Clair }\end{array}$ \\
\hline 1 & 2 & 3 & 4 & 5 & 7 \\
\hline $\begin{array}{l}\text { MONOGENEA } \\
\text { Gyrodactylus proterorhini } \\
\text { CESTODA }\end{array}$ & + & & + & & \\
\hline $\begin{array}{l}\text { Proteocephalus sp. } \\
\text { Triaenophorus crassus } \mathrm{pl} \\
\text { DIGENEA } \\
\text { Apatemon cobitidis }\end{array}$ & + & & & + & + \\
\hline proterorhini met & & & + & + & \\
\hline Diplostomum spathaceum met & & & & + & \\
\hline Nicolla skrjabini & + & & & & \\
\hline Plagioporus skrjabini & & + & & & \\
\hline $\begin{array}{l}\text { Tylodelphys clavata met } \\
\text { NEMATODA }\end{array}$ & & & & + & \\
\hline Anguillicola crassus L3 & & & & + & \\
\hline Camallanus lacustris & & & & + & \\
\hline Eustrongylides excisus L3 & + & & & & \\
\hline Philometra ovata L3 & & & & + & \\
\hline Pseudocapillaria tomentosa & & & & + & \\
\hline Raphidascaris acus L3 & & & & + & + \\
\hline $\begin{array}{l}\text { Spiroxys contortus L3 } \\
\text { ACANTHOCEPHALA }\end{array}$ & & & & & + \\
\hline Acanthocephalus lucii & + & & & + & \\
\hline A. anguillae & & & & + & \\
\hline Leptorhynchoides thecatus & & & & & + \\
\hline Neoechynorhynchus sp. ca & & & & & + \\
\hline $\begin{array}{l}\text { Southwellina hispida ca } \\
\text { MOLLUSCA }\end{array}$ & & & & & + \\
\hline $\begin{array}{l}\text { Glochidium sp. } \\
\text { CRUSTACEA }\end{array}$ & & + & & + & \\
\hline Argulus foliaceus & & & & + & \\
\hline Species number & 5 & 2 & 2 & 13 & 6 \\
\hline
\end{tabular}

Look material and methods for abbreviations. 


\section{Acknowledgment}

We would like to thank Alisha Hayden (Health Organisation of Utah, USA) for English corrections.

\section{References}

Belofastova, I. P., (2007): Acanthocephalan parasite systems of the Black Sea fishes under anthropogenic factors. Ekologiya Morya, 73: 16 - 20 (in Russian)

BERG, L. S., (1949): Freshwater fishes of the USSR and adjacent countries. Publications of Academy of Sciences of USSR, Moscow and Leningrad (in Russian)

Bush, A. O., Lafferty, K. D., Lotz, J. M., Shostak, A. W. (1997): Parasitology meets ecology on its own terms: Margolis et al. revisited. J. Parasitol., 83: 575 - 583

BUTENKO, O. I. (2000): Molluscs of coastal shallow waters of the Odessa Bay. Ekologiya Morya, 52: 44 - 47 (in Russian)

ChaplinA, O. M., AnTsyshKInA, A. M. (1961): Materials to parasite fauna of small rivers of the Northern coast of the Sea of Azov. Dopovidi AN URSR, 2: 247 - 250 (in Ukrainian)

ChERnYSHENKo, A. S. (1960): Parasite fauna of fishes of the Hryhorivsky Estuary. In Chepurnov, V. S. (Ed): Proceedings of $1^{\text {st }}$ Ichthyological Conference on the Study of Marine Estuaries of the northwestern Black Sea. University of Chişinău, Chişinău, 205-211 (in Russian)

Chernyshenko, A. S. (1966): Parasite fauna of fishes of estuaries of the North-Western Black Sea region (ecological-faunistic review). In VODYANITSKIY, V. A., VINOGRADOV, K. A., DolgopolsKayA, M. A., GReZE, V. N., REVIN, A. S., Kalugina, A. A., DenisenKo, I. F., and Delamure, S. L. (Eds): Helminthofauna of animals of the southern seas. Naukova Dumka, Kiev, 105 - 113 (in Russian)

Chiriac E., Udrescu M. (1957): Contribuții la conoaşterea parasiţilor peştilor din Balta Comana. Nota I Monogenoidea. Analele Univ. C.I. Parhon-Bucureşti, Ser. Şt. Naturii, 13: 149 - 155

Copp, G. H., Bianco, P. G., Bogutskaya, N. G., Erös, T., FAlKa, I., Ferreira, M. T., FoX, M. G., FreyHOF, J., GOZLAN, R. E., GrabowsKa, J., KovÁČ, V., MORENO-AMICH, R., Naseka, A. M., Peñáz, M., PovŽ, M., Przybylski, M., Robillard, M., Russell, I. C., Stakénas, S., Šumer, S., Vila-Gispert, A., Wiesner, C. (2005): To be, or not to be, a non-native freshwater fish? J. Appl. Ichthyol., 21: 242 $-262$

CzekAnOwski, J. (1909): Zur differential diagnose der Neandertalgruppe. Korespondblatte der deutschen. Gesellschaft der Anthropologie, 40: 44 - 47

DE Buron, I., Chauvet, C. (2003): Étude comparée de l'acanthocéphale Acanthocephaloides propinquus dans deux espèces de gobies de l'Étang de Thau (Hérault, France). In ComBes, C. and Jourdane, J. (Eds): Taxonomie, écologie et évolution des métazoaires parasites, Vol. 1. PUP, Perpignan, $235-247$

Dezfuli, B. S., Franzoi, P., Trisolini, R., Rossi, R. (1989): On the crustacean hosts of larval acanthocephalan parasites of fishes from a coastal lagoon of River Po delta. Parassitologia, 31: $51-57$

Gaevskaya, A. V., DMitrieva, E. V. (1997): The review of monogenean fauna of the Black Sea. Ekologiya Morya, 46: 7 - 17 (in Russian)

ERGENS, R. (1962): New species of the genus Gyrodactylus Nordmann, 1832 (Monogenoidea) of Czechoslovak fauna. Folia Zool., 11(4): 327-331

ERGENS, R. (1967): New species of the genus Gyrodactylus (Monogenoidea) from the Danube basin. Folia Parasitol., 19(4): 377-379

ERös, T., SAVcsic, A., TóTH, B. (2005): Abundance and night-time habitat use patterns of Ponto-Caspian gobiid species (Pisces, Gobiidae) in the littoral zone of the River Danube, Hungary. J. Appl. Ichthyol., 21: 350 - 357

FREYHOF, F. (2003): Immigration and potential impacts of invasive freshwater fishes in Germany. In IGB LeibnizInstitut für Gewässerökologie und Binnenfischerei im Forschungsverbund, Annual Report 2002. e. V., Berlin, 51 $-58$

Freyhof, F., NASEKA, A. M. (2007): Proterorhinus tataricus, a new tubenose goby from Crimea, Ukraine. Ichthyol. Explor. Freshwaters, 18(4): 325-334

Grabowska, J., PIETRAszewsKi, D., OndRaČKOVÁ, M. (2008): Tubenose goby Proterorhinus marmoratus (Pallas, 1814) has joined three other Ponto-Caspian gobies in the Vistula River (Poland). Aquatic Invasions, 3(2): 261-265

HARKA, Á. (1990): Zusätzliche Verbreitungsgebiete der Marmorierten Grundel (Proterorhinus marmoratus Pallas) in Mitteleuropa. Österreichs Fischerei, 43: 262-265

Jude, D. J., REIDER, R. H., SMITH, G. R. (1992): Establishment of Gobiidae in the Great Lakes basin. Can. J. Fish. Aquat. Sci., 49: 416 - 421

KotTelat, M., FreyHof, J., (2007): Handbook of European freshwater fishes. Cornol, Switzerland and Berlin, Germany.

KouBKOVÁ, B., BARUŠ, V. (2000): Metazoan parasites of the recently established tubenose goby (Proterorhinus marmoratus: Gobiidae) population from the South Moravian reservoir, Czech Republic. Helminthologia, 37(2): $89-95$

KøIE, M. (2001): The life cycle of Dichelyne (Cucullanellus) minutus (Nematoda: Cucullanidae). Folia Parasitol., 48: $304-310$

KVACH, Y. (2005): A comparative analysis of helminth faunas and infection of ten species of gobiid fishes (Actinopterygii: Gobiidae) from the North-Western Black Sea. Acta Ichthyol. Pisc., 35(2): $103-110$

KVACH, Y., StePIEN, C. A. (2008): Metazoan parasites of introduced round and tubenose gobies in the Great Lakes: support for the "enemy release hypothesis", J. Great Lakes Res., 34: $23-25$

Losovskaya, G. V., Sinegub, I. A., Shurova, N. M. (2006): The list of species of macrozoobenthos. In Zaitsev, Yu. P., Aleksandrov, B. G., and Minicheva, G. G. (Eds): Northwestern part of the Black Sea: biology and ecology. Naukova Dumka, Kiev, 595 - 601 (in Russian) 
Machkevsky, V. K., Mordvinova, T. N., Parukhin, A. M. (1990): The helminth fauna of gobies of the Gulf of Yegorlyk and Lake Donuzlav - places of allocation of the mussels farms. Ekologiya Morya, 36: 69 - 75 (in Russian)

MAILlard, C. (1975): Étude du cycle évolutif du Trématode: Acanthostomum imbutiforme (Molin, 1859) Gohar, 1934, parasite de Morone labrax (Linné, 1758). Ann. Parasit. Hum. Comp., 48(1): 33 - 46

MAnNé, S. Poulet N. (2008): First record of the western tubenose goby Proterorhinus semilunaris (Heckel, 1837) in France. Knowl. Managt. Aquatic Ecosyst., 389: 03p1 03p5

MArgaritov, N. M. (1960): Parasites of some of our sea fishes. Trudove na nauchni institut rybarstva $i$ ribna promishlenost - Varna, 2: 195 - 213 (in Bulgarian)

MoRAVEC, F. (1994): Parasitic nematodes of freshwater fishes of Europe. Academia and Kluwer Academic Publishers, Prague, Dordrecht, Boston, London

Muzzall, P., Peebles, C. R., Thomas, M. V. (1995): Parasites of the round goby, Neogobius melanostomus, and tubenose goby, Proterorhinus marmoratus (Perciformes: Gobiidae), from the St. Clair River and Lake St. Clair, Michigan. J. Helminthol. Soc. Wash., 62(2): 226 - 228

NAIDENOVA, N. N. (1974): Parasitofauna of fishes of gobiid family of the Black Sea and the Sea of Azov. Naukova Dumka, Kiev (in Russian)

NeIlson, M. E., Stepien C. A. (2009): Evolution and phylogeography of the tubenose goby genus Proterorhinus (Gobiidae: Teleostei): evidence for new cryptic species. Biol. J. Linnean Soc., 96: 664 - 684

OndRaČKOVÁ, M., DÁVIDOVÁ, M., PEČínKOVÁ, M., BLAŽEK, R., Gelnar, M., VAlOVÁ, Z., ČERnÝ, J., JurajdA, P. (2005): Metazoan parasites of Neogobius fishes in the Slovak section of the River Danube. J. Appl. Ichthyol., 21: $345-349$

Pinchuk, V. I., Smirnov, A. I., Koval, N. V., ShevchenKO, P. G. (1985): On recent distribution of the gobiid fishes (Gobiidae) in the Dnieper River basin. In Hydrobiological investigations of fresh waters. Naukova Dumka, Kiev, 121 - 130 (in Russian)

PRÁŠEK, V., JURAJdA, P. (2005): Expansion of Proterorhinus marmoratus in the Morava River basin (Czech Republic, Danube R. watershed). Folia Zool., 54(1 $-2): 189-192$

Pronin, N. M., Fleischer, G. W., Baldanova, D. R., ProninA, S. V. (1997): Parasites of the recently establish- ed round goby (Neogobius melanostomus) and tubenose goby (Proterorhinus marmoratus) (Gobiidae) in the St. Clair River and Lake St. Clair, Michigan, USA. Folia Parasitol., 44: $1-6$

ReInARTZ, R., Hilbrich, T. (2000): Nachweis der Marmorierten Grundel im unterfränkischen Mein bei Eltmann (Rheineinzugsgebiet). Österreichs Fischerei, 53: $192-194$

Rizevsky, V., Pluta, M., Leschenko, A., Ermolaeva, I. (2007): First record of the invasive Ponto-Caspian tubenose goby Proterorhinus marmoratus (Pallas, 1814) from the River Pripyat, Belarus. Aquatic Invasions, 2(3): 275-277

SMIRNOV, A. I. (1986): Perch-likes (gobiids), scorpionfishes, flatfishes, clingfishes, anglerfishes. In Fauna of Ukraine, Vol. 8, Issue 5. Naukova Dumka, Kiev (In Russian)

Sørensen, T. A. (1948): A new method of establishing groups of equal amplitude in plant sociology based on similarity of species content and its application to analysis of vegetation on Danish commons. Rgl. Dan Vidensk Selsk Biol. Skr., 5: $1-34$

STENKO, R. P. (1976) Life cycle of the trematode Crowcrocoecum skrjabini (Iwanitzky, 1928) (Allocreadiata, Opecoelidae). Parazitologiya, 10(1): 9 - 16 (In Russian)

STEPIEN, C. A., TumeO, M. A. (2006): Invasion genetics of Ponto-Caspian gobies in the Great Lakes: a "cryptic" species, absence of founder effects, and comparative risk analysis. Biological Invasions, 8: $61-78$

VoJTEK, J. (1964): Zur Kenntnis des Entwicklungszyklus von Apatemon cobitidis (Linstow, 1890). Zeitschrift für Parasitenkunde, 24: 578 - 599

ZANDER, C. D. (1998): Ecology of host parasite relationships in the Baltic Sea. Naturwissenschaften, 85: 426 - 436 ZANDER, C. D. (2004): Four-year monitoring of parasite communities in gobiid fishes of the south-western Baltic. II. Infracommunity. Parasitol. Res., 93: 17 - 29

Zander, C. D., Reimer, L. W., BArZ, K., Dietel, G., StrohbACH, U. (2000): Parasite communities of the Salzhaff (Northwest Mecklenburg, Baltic Sea). II. Guild communities, with special regard to snails, benthic crustaceans, and small-sized fish. Parasitol. Res., 86: 359 - 372 ZANDER, C. D., Strohbach, U., Groenewold, S. (1993): The importance of gobies (Gobiidae, Teleostei) as hosts and transmitters of parasites in the SW. Helgoländer Meeresunters., 47: 81 - 111 